\title{
Biochemical and Biological Influences of Sub-Lethal Concentrations of Emamectin Benzoate and Certain IGR Insecticides against Spodoptera littoralis (Lepidoptera: Noctuidae)
}

\author{
Eman K. El-sayed 1, M. A. Z. Massoud ${ }^{2}$ and Manal A. Attia ${ }^{3 *}$
}

\begin{abstract}
Toxicity and sub-lethal effects of Emamectin benzoate and IGR 's (lufenuron - flufenoxuron) were evaluated against the $2^{\text {nd }}$ instar larvae of cotton leafworm, Spodopter alittoralis. The biochemical influences of these agrochemicals with the polyphenol oxidase (PPO) of the treated larvae were investigated (invivo). Emamectin benzoate $\left(\mathrm{LC}_{50}=0.007 \mathrm{mg} \mathrm{L}^{-1}\right)$ was approximately 34 and 83 times more toxic than lufenuron $\left(\mathrm{LC}_{50}=0.24 \mathrm{mg} \mathrm{L}^{-1}\right)$ and flufenoxuron $\left(\mathrm{LC}_{50}=0.58 \mathrm{mg} \mathrm{L}^{-1}\right)$, respectively. Lufenuron was approximately 2 times more toxic than flufenoxuron. The $2^{\text {nd }}$ instar larvae treated with the sublethal concentrations ( $\mathrm{LC10}$ and $\mathrm{LC}_{25}$ ) of emamectin benzoate, lufenuron or flufenoxuron showed significant $(P$ $<0.05$ ) reduce of larval body weights, pupation $\%$, pupal mean weight and adult emergence\%. While the average time of the pupation for the larvae that given concentrations equivalent to the $L_{10}$ and $L_{25}$ of lufenuron and flufenoxuron, were significantly longer than the untreated larvae. On the other hand larval duration for the larvae that given concentrations equivalent to the $\mathbf{L C}_{10}$ and $\mathrm{LC}_{25}$ of emamectin benzoate did not differ significantly compared with the untreated larvae. The fecundity and fertility were strongly reduced in all insecticide treatments compared with check untreated. The PPO activity was partially decreased in the treated larvae (with all insecticide treatments) in a concentration dependent manner. These results suggest that, sublethal concentrations of emamectin benzoate, lufenuron and flufenoxuron may reduce the population growth of $S$. littoralis by affecting its development and reproduction.
\end{abstract}

Key words: Spodoptera littoralis; IGRs; Emamectin benzoate; Sub-lethal effects and PPO.

\section{INTRODUCTION}

Cotton leafworm, Spodoptera littoralis (Boisduval), is one of the most destructive agricultural lepidopterous pests of cotton and vegetable plants in Egypt (Hatem et al., 2009). The insect occurs during the whole cycle of cotton, causing considerable damage by feeding on leaves, fruiting points, flower buds and occasionally, bolls. So, it requires several insecticide applications to control.

\footnotetext{
*corresponding author: Manal A. Attia (Manal.attia77@gmail.com)

${ }^{1}$ Plant Protection Research Institute ARC

${ }^{2}$ Faculty of Agriculture. Alexandria University- Saba basha

${ }^{3}$ Center Agricultural Pesticides laboratory (CAPL),

Agriculture research Center (ARC)

Received March 27, 2017, Accepted May 30, 2017
}

Commonly, control of this pest has largely been depending on the use of neurotoxic insecticides including organophosphates, carbamates and pyrethroids (Ahmad et al., 2009). The intensive application of these insecticides has give rise to $S$. littoralis populations resistant to all of these groups (Abou-Taleb, 2010). Selective insecticides with modes of action differed from those insecticide groups are highly desirable in integrated pest management (IPM) programs. Among these insecticides are insect growth regulators (IGRs) and avermectin insecticide group.

IGRs were developed to mimic, block or otherwise interact with the hormonal system of insects (Oetken et al., 2004). These include the juvenile hormone analogues, the ecdysone agonists and the chitin synthesis inhibitors (CSIs) (Graf, 1993; Tunaz and Uygun, 2004). Among the chitin synthesis inhibitors, acylureas (BPUs) are gaining importance in insect pest control because they are relatively harmless to natural enemies (Furlong et al., 1994).

Chemical modifications on the abamectin (avermectins) structure resulted in the discovery of emamectin benzoate (Mrozik, 1994). Emamectin benzoate is very effective against a broad spectrum of lepidopteran pests including the Egyptian cotton leafworm (Abou-Taleb et al., 2009). It modulates specific glutamate-gated anion channels in synapses and muscle cells (Roberts and Hutson, 1999), thereby increasing the influx of chloride ions. This hyperpolarizes the cell and prevents depolarization of the neuromuscular endplate beyond the threshold level (Davies and Rodger, 2000).

The use of insecticides may result in multiple sublethal effects on insect pests (Singh and Marwaha, 2000 and Sabri et al 2017), such as physiological effects may be manifested as reductions in life span (Stark and Rangus, 1994), development rate (Cripe et al., 2003), fertility (Liu and Trumble, 2005), fecundity (Zalizniak and Nugegoda, 2006), changes in sex ratio (Coutyet al., 2001). These sub-lethal effects as well as mortality must be considered when examining the total effects of 
insecticides (Yin et al., 2008). Moreover, these sublethal doses may interfere with some biochemical process such as the related enzymes activity.One of the related enzymes to IGR's mode of action are phenoloxidases that related to critical steps of melanization reactions, which are crucial for the sclerotization of a new cuticle after ecdysis (Andersen, 2005) and for the encapsulation of pathogens in the hemolymph (Soderhall and Cerenius, 1998).

So, the objectives of the present study were to investigate the sub-lethal effects of lufenuron, flufenoxuron and emamectin benzoate on some biological aspects of $S$. littoralis, including development time, fecundity, larval and pupal weights and adult emergence. As well we investigate the effect of the sublethal concentrations of these insecticides on the polyphenol oxidase (PPO) activity.

\section{MATERIALS AND METHODS}

\section{Experimental insect:}

A susceptible strain of the $S$. littoralis has been reared for many years in the Plant Protection Research Station, Agricultural Research Center, Alexandria, Egypt. Larvae were fed castor oil leaves under controlled laboratory conditions $\left(25 \pm 2{ }^{\circ} \mathrm{C}, \mathrm{RH} 65 \%\right)$ for several years avoiding exposure to any pesticides according to the method of Eldefrawi et al., (1964).

\section{Test insecticides and other chemicals:}

Formulated emamectin benzoate (Proclaim ${ }^{\circledR} \quad 5 \%$ SG), lufenuron (Match ${ }^{\circledR} 5 \%$ EC) and flufenoxuron (Cascade $^{\circledR} 10 \%$ EC) were obtained from Syngenta Co. Bovine serum albumin (BSA), Folin-Ciocalteu phenol reagent and pyrocatechol were purchased from SigmaAldrich Chemical Co., USA. All chemicals were used without further purification.

\section{Bioassay and determination of sub-lethal concentrations:}

A leaf dip bioassay method (Eldefrawi et al., 1964) was used. Castor oil leaf disks (35 $\mathrm{mm}$ in diameter) were dipped in the desirable concentration of insecticide prepared in distilled water contained $0.05 \%(\mathrm{~V} / \mathrm{V})$ triton $\mathrm{X}-100$ for $10 \mathrm{sec}$., and dried at room temperature. For each tested insecticide a series of 6-8 concentrations were tested. The control containing pure water was also used with Triton X-100 as an emulsifier $(0.05 \% \mathrm{~V} / \mathrm{V}))$. The treated castor oil leaf disks were introduced to ten $2^{\text {nd }}$ instar larvae $(2.3 \pm 0.1 \mathrm{mg} /$ larva $)$, which had been starved for two hrs. The cups were covered with lids and maintained at $25 \pm 2{ }^{\circ} \mathrm{C}$. Each concentration was replicated five times. After $24 \mathrm{hrs,} \mathrm{fresh} \mathrm{untreated} \mathrm{castor}$ oil leaf pieces were added to each cup. Mortality was recorded after $2496 \mathrm{hrs}$ and corrected according to Abbott equation (Abbott, 1925). The sub-lethal concentrations $\left(\mathrm{LC}_{25}\right.$ and $\mathrm{LC}_{10}$ ) were calculated from the Ldp-line equation obtained after $96 \mathrm{hrs}$ and used for the subsequent experiments.

Latent effects of sublethal concentrations of emamectin benzoate, lufenuron and flufenoxuron against $S$. littoralis:

Castor oil leaves were soaked in the previously determined LC25 and $\mathrm{LC}_{10}$ equivalent concentrations for tested insecticides. Four hundred $2^{\text {nd }}$ instar larvae $(2.3 \pm$ $0.1 \mathrm{mg} /$ larva) in 4 replicates were used for each treatment and provided with treated leaves. After $24 \mathrm{hrs}$, surviving larvae were transferred to jars containing fresh untreated leaves and observed daily for pupation and eclosion. Pupae were sexed and weighed $24 \mathrm{hrs}$ after formation. Larval, pupal and adult durations and survivorship were determined, as well as, larval \& pupal weights and the percentages of adult emergence. Resulted adults were placed in plastic cups provided with a folded sheet paper as oviposition site. Two adult males were kept with one adult female to maximize the probability of successful mating. The sub-lethal effects of various insecticides on fecundity (total number of eggs / female) and fertility (hatchability percentages of eggs) were determined. Mating of untreated adults of both sexes were used as control. Initially, 12 mating were planned for each insecticide treatment as well as control. The mating cups were check daily and egg masses were removed until female death. The total number of eggs /female for each mating and hatched eggs percentages were evaluated.

\section{Polyphenol oxidase (PPO) activity assay:}

Crude enzyme preparation: Surviving larvae treated with $\mathrm{LC}_{25}$ and $\mathrm{LC}_{10}$ values of each insecticide, after 96 hrs of treatment and the untreated (control) were starved for two hrs. Then three grams of total larvae from each treatment or control were homogenized in $10 \mathrm{ml}$ of $0.1 \mathrm{M}$ potassium phosphate buffer $(\mathrm{pH}$ 7.0) using Polytron Kinemetica on ice. The homogenate was filtered through two layers of cheesecloth and centrifuged at $10,000 \mathrm{rpm}$ for $10 \mathrm{~min}$ at $4{ }^{\circ} \mathrm{C}$ using Cryofuge 20-3, Heraeus Christ centrifuge. The supernatant was used as the crude enzyme extract. Lowry et al. (1951) method was used to determine protein content in the supernatant comparing to the standard curve of BSA.

Enzyme activity determination: The activity of PPO was determined according to Zhi-qinget al. (2008) by mixing of $1.5 \mathrm{ml} 0.2 \mathrm{M}$ pyrocatechol, $1.4 \mathrm{ml}$ of $0.05 \mathrm{M}$ phosphate buffer, $\mathrm{pH} 6.8$ and $0.1 \mathrm{ml}$ enzyme extract, respectively. The mixture was incubated at $25^{\circ} \mathrm{C}$ for 30 min and the absorbance was measured at $420 \mathrm{~nm}$ using a Sequoia-Turner Model 340 spectrophotometer. The 
specific activity of PPO was calculated as $\mathrm{OD}_{420} /$ $\mathrm{min} / \mathrm{mg}$ protein.

\section{Statistical analysis:}

The $\mathrm{LC}_{50}$ 's and their $95 \%$ fiducial limits of the tested insecticides were obtained using the POLO program (Russell et al., 1977) based on Finney (1971). All other quantitative estimations were replicated four times and the values are expressed as mean \pm standard error. The SAS 8.0 software was used for analysis of the data obtained from each experiment and the means were tested for significant differences by Duncan's multiple range tests at $\mathrm{P}=0.05$.

\section{RERSULTS}

Toxicity of emamectin benzoate, lufenuron and flufenoxuron against $2^{\text {nd }}$ instar $S$. littoralis larvae:

Susceptibility of $2^{\text {nd }}$ instar larvae of $S$. littoralis to emamectin benzoate, lufenuron and flufenoxuron after $96 \mathrm{hrs}$ of exposure is presented in Table (1). Emamectin benzoate $\left(\mathrm{LC}_{50}=0.007 \mathrm{mg} \mathrm{L}^{-1}\right)$ was approximately 34 and 83 times more toxic than lufenuron $\left(\mathrm{LC}_{50}=0.24 \mathrm{mg}\right.$ $\left.\mathrm{L}^{-1}\right)$ and flufenoxuron $\left(\mathrm{LC}_{50}=0.58 \mathrm{mg} \mathrm{L}^{-1}\right)$, respectively. Lufenuron was approximately 2 times more toxic than flufenoxuron. The $\mathrm{LC}_{25}$ and $\mathrm{LC}_{10}$ values after $96 \mathrm{hrs}$ of exposure are 0.002 and $0.001 \mathrm{mg} \mathrm{L}^{-1}$ for emamectin benzoate, 0.064 and $0.028 \mathrm{mg} \mathrm{L}^{-1}$ for lufenuron, and 0.16 and $0.06 \mathrm{mg} \mathrm{L}^{-1}$ for flufenoxuron.

Sub-lethal effects of emamectin benzoate, lufenuron and flufenoxuron on some biological aspects of $S$. littoralis:

Sub-lethal effects of tested insecticides against $S$. littoralis larvae are presented in Tables (2, 3 and 4). The average weight of treated larvae was decreased significantly compared to control during the observation period. It is clear that, the higher concentration of all tested insecticides $\left(\mathrm{LC}_{25}\right)$ were significantly the highest in the effect in reducing the larval weight. When larvae were treated with emamectin benzoate at $\mathrm{LC}_{25}(0.002$ $\mathrm{mgL}^{-1}$ ), the larval weight averages were $32.6,126.7$ and $422.3 \mathrm{mg} /$ larva compared to $44.7,186.2$ and $602.5 \mathrm{mg}$ / larva in control after 5, 10 and 15 days of treatment, respectively. The larval weight averages were 34.1, 137.2 and $426.5 \mathrm{mg} /$ larva, and 37.4, 142.5 and 431.0 $\mathrm{mg} /$ larva when larvae were treated with $\mathrm{LC}_{25}$ of lufenuron $\left(0.064 \mathrm{mgL}^{-1}\right)$ and flufenoxuron $\left(0.16 \mathrm{mgL}^{-1}\right)$ after 5, 10 and 15 days of treatment, respectively (Table 2).

The average time to the pupation for larvae given concentrations equivalent to the $\mathrm{LC}_{10}$ and $\mathrm{LC}_{25}$ of lufenuron and flufenoxuron treatments were significantly longer than those given the control treatment. These times were 22.2 and 23.7 days for lufenuron and 22.4 and 23.1 days for flufenoxuron at $\mathrm{LC}_{10}$ and $\mathrm{LC}_{25}$, respectively, where it was 18.4 days for control. Larval duration for larvae given concentrations equivalent to the $\mathrm{LC}_{10}$ and $\mathrm{LC}_{25}$ of emamectin benzoate treatments did not differ significantly compared to larvae given control treatment (Table 2).

Table 1. Toxicity of emamectin benzoate, lufenuron and flufenoxuron against the $2^{\text {nd }}$ instar larvae of $S$. littoralis after $96 \mathrm{hrs}$ of exposure

\begin{tabular}{lccccc}
\hline Insecticide & $\mathbf{L C}_{\mathbf{5 0}}\left(\mathbf{m g ~ L}^{\mathbf{- 1}}\right)$ & Confidence limits & Slope $\pm \mathbf{S E}$ & $\mathbf{L C}_{\mathbf{2 5}} \mathbf{( \mathbf { m g ~ L } ^ { \mathbf { - 1 } } )}$ & $\mathbf{L C}_{\mathbf{1 0}} \mathbf{( \mathbf { m g ~ L } ^ { \mathbf { 1 } } )}$ \\
\hline Emamectin benzoate & 0.007 & $(0.006-0.009)$ & $1.70 \pm 0.08$ & 0.002 & 0.001 \\
Lufenuron & 0.240 & $(0.18-0.34)$ & $1.66 \pm 0.11$ & 0.064 & 0.028 \\
Flufenoxuron & 0.580 & $(0.42-80)$ & $1.54 \pm 0.12$ & 0.16 & 0.06 \\
\hline
\end{tabular}

Table 2. Effect of sub-lethal concentrations of emamectin benzoate, lufenuron and flufenoxuron on the larval weight, larval duration and pupation percentage of the $2^{\text {nd }}$ instar larvae of $S$. littoralis

\begin{tabular}{|c|c|c|c|c|c|c|}
\hline \multirow{3}{*}{ insecticide } & \multirow{2}{*}{$\begin{array}{c}\text { Conc. } \\
\left(\mathrm{mg} \mathrm{L}^{-1}\right) \\
\end{array}$} & \multicolumn{3}{|c|}{ Days after treatment } & \multirow{3}{*}{$\begin{array}{l}\text { Larval duration } \\
\text { (days) } \pm \mathrm{SE}\end{array}$} & \multirow{3}{*}{$\begin{array}{l}\text { Pupation\% } \\
\quad \pm \mathrm{SE}\end{array}$} \\
\hline & & 5 & 10 & 15 & & \\
\hline & & \multicolumn{3}{|c|}{ Mean weight (mg\Larva) $\pm \mathrm{SE}$} & & \\
\hline Control & - & $44.7^{\mathrm{a}} \pm 1.5$ & $186.2^{\mathrm{a}} \pm 3.2$ & $602.6^{\mathrm{a}} \pm 5.9$ & $18.4^{b} \pm 1.3$ & $98.1^{\mathrm{a}} \pm 1.0$ \\
\hline \multirow[t]{2}{*}{ Emamectin benzoate } & 0.001 & $38.2^{\mathrm{b}} \pm 2.4$ & $160.9^{\mathrm{c}} \pm 5.2$ & $510.2^{\mathrm{c}} \pm 4.5$ & $17.8^{\mathrm{b}} \pm 0.6$ & $82.0^{\mathrm{b}} \pm 1.6$ \\
\hline & 0.002 & $32.6^{c} \pm 2.1$ & $126.7^{\mathrm{e}} \pm 1.9$ & $422.3^{\mathrm{d}} \pm 6.7$ & $19.3^{\mathrm{b}} \pm 1.5$ & $77.6^{c} \pm 2.6$ \\
\hline \multirow[t]{2}{*}{ Lufenuron } & 0.028 & $38.2^{\mathrm{b}} \pm 1.4$ & $166.3^{c} \pm 3.0$ & $501.3^{\mathrm{c}} \pm 3.8$ & $22.2^{\mathrm{a}} \pm 1.8$ & $72.6^{\mathrm{de}} \pm 1.2$ \\
\hline & 0.064 & $34.1^{\mathrm{c}} \pm 0.7$ & $137.2^{\mathrm{d}} \pm 4.3$ & $426.5^{\mathrm{d}} \pm 3.6$ & $23.7^{\mathrm{a}} \pm 1.7$ & $61.7^{\mathrm{f}} \pm 0.40$ \\
\hline \multirow[t]{2}{*}{ Flufenoxuron } & 0.06 & $40.0^{\mathrm{b}} \pm 1.2$ & $174.6^{b} \pm 2.9$ & $532.6^{\mathrm{b}} \pm 6.2$ & $22.4^{\mathrm{a}} \pm 1.4$ & $76.1^{\mathrm{cd}} \pm 1.6$ \\
\hline & 0.16 & $37.4^{\mathrm{b}} \pm 1.4$ & $142.5^{\mathrm{d}} \pm 5.3$ & $431.0^{\mathrm{d}} \pm 4.8$ & $23.1^{\mathrm{a}} \pm 0.8$ & $69.3^{\mathrm{e}} \pm 1.7$ \\
\hline
\end{tabular}

Within a column, means possessing the same letter do not differ significantly at $P=0.05$. 
Sub-lethal concentrations of tested insecticides had a considerable effect on pupation (Table 2). The $\mathrm{LC}_{25}$ treatment of lufenuron gave the lowest pupation percentage $61.7 \%$ compared to $98.1 \%$ in control treatment. Also, significant decrease in pupation percentage was achieved with the $\mathrm{LC}_{10}$ of lufenuron (72.6\%). The $\mathrm{LC}_{10}$ and $\mathrm{LC}_{25}$ of emamectin benzoate and flufenoxuron gave (82.0 and 77.6\%) and (76.1 and $69.3 \%$ ) of pupation, respectively compared to control treatment $(98.1 \%)$.

As shown in Table (3), all treatments significantly reduced the mean of pupal weight compared to control treatment. The averages of pupae weight were 275.2 and $251.1 \mathrm{mg} /$ pupa in the $\mathrm{LC}_{10}$ and $\mathrm{LC}_{25}$ of emamectin benzoate treatments, respectively, compared to 293.5 $\mathrm{mg} /$ pupa in the control treatment. In case of $\mathrm{LC}_{10}$ and $\mathrm{LC}_{25}$ of lufenuron treatments, pupae weight averages were 265.6 and $240.4 \mathrm{mg} /$ pupa, respectively. Finally, pupae weight averages were 267.6 and $248.5 \mathrm{mg} /$ pupa in the $\mathrm{LC}_{10}$ and $\mathrm{LC}_{25}$ of flufenoxuron treatments, respectively. However, pupal duration did not changed significantly in all treatments compared to control (Table 3). Reduction percentage in the adult emergence rates were significantly occurred in all treatments. Adult emergence percentages were 88.4 and $76.2 \%$ in the $\mathrm{LC}_{10}$ and $\mathrm{LC}_{25}$ of emamectin benzoate treatments, respectively, compared to $97 \%$ in the control treatments.
The $\mathrm{LC}_{25}$ of both lufenuron and flufenoxuron caused the highest reduction in the adult emergence, where the adult emergence percentages were 65.6 and 66.4, respectively.

Table(4) represents the effect of insecticide treatments on the adult fecundity, fertility and longevity. Flufenoxuron and lufenuron at $\mathrm{LC}_{25}$ caused the highest effect on the adult fecundity where the average number of eggs laid / female were 328.5 and 340.8 / female, respectively, compared to 544.3 / female in control treatment. Also, lufenuron and flufenoxuron at the $\mathrm{LC}_{10}$ significantly decreased the adult fecundity where the average number of eggs laid / female were 385.3 and 347.6 / female, respectively. Emamectin benzoate at $\mathrm{LC}_{10}$ and $\mathrm{LC}_{25}$ was significantly decreased the average of eggs laid / female to 507.5 and 495.5 / female, respectively, compared to 544.3 / female in control treatment. The fertility (percentages of hatched eggs) were significantly decreased as a result of all insecticides treatments. Whereas the percentages of hatched eggs were $(88.5$ and $85.8 \%)$, (76.3 and $64.2 \%)$ and (74.6 and $67.7 \%$ ) for the $\mathrm{LC}_{10}$ and $\mathrm{LC}_{25}$ of emamectin benzoate, lufenuron, and flufenoxuron, respectively, compared to $97.4 \%$ in the control treatment. On the other hand, adult longevity did not differ significantly in all insecticides treatments compared with the control treatment.

Table 3. Effect of sub-lethal concentrations of emamectin benzoate, lufenuron and flufenoxuron on the pupal weight, pupal duration and adult emergence of the $2^{\text {nd }}$ instar larvae of $S$. littoralis

\begin{tabular}{|c|c|c|c|c|}
\hline Insecticide & $\begin{array}{c}\text { Conc. } \\
\left(\mathrm{mg} \mathrm{L}^{-1}\right)\end{array}$ & $\begin{array}{c}\text { Pupal mean weight } \\
\text { (mg/pupa) } \pm \mathrm{SE}\end{array}$ & $\begin{array}{c}\text { Pupal duration (days) } \\
\pm \mathrm{SE}\end{array}$ & $\begin{array}{c}\text { Adult emergence } \% \\
\pm \mathrm{SE}\end{array}$ \\
\hline Control & - & $293.5^{\mathrm{a}} \pm 3.4$ & $8.4^{\mathrm{a}} \pm 0.6$ & $97.0^{\mathrm{a}} \pm 0.2$ \\
\hline \multirow[t]{2}{*}{ Emamectin benzoate } & 0.001 & $275.2^{\mathrm{b}} \pm 2.7$ & $8.2^{\mathrm{a}} \pm 0.4$ & $88.4^{\mathrm{b}} \pm 2.3$ \\
\hline & 0.002 & $251.1^{\mathrm{c}} \pm 3.1$ & $8.3^{\mathrm{a}} \pm 0.4$ & $76.2^{\mathrm{d}} \pm 1.5$ \\
\hline \multirow[t]{2}{*}{ Lufenuron } & 0.028 & $265.6^{\mathrm{b}} \pm 2.7$ & $8.3^{\mathrm{a}} \pm 0.5$ & $82.4^{c} \pm 2.4$ \\
\hline & 0.064 & $240.4^{c} \pm 3.2$ & $8.4^{\mathrm{a}} \pm 0.5$ & $65.6^{\mathrm{e}} \pm 1.8$ \\
\hline \multirow[t]{2}{*}{ Flufenoxuron } & 0.06 & $267.6^{\mathrm{b}} \pm 2.4$ & $8.5^{\mathrm{a}} \pm 0.4$ & $79.3^{\mathrm{cd}} \pm 2.1$ \\
\hline & 0.16 & $248.5^{c} \pm 1.9$ & $8.4^{\mathrm{a}} \pm 0.5$ & $66.4^{\mathrm{e}} \pm 1.7$ \\
\hline
\end{tabular}

Within a column, means possessing the same letter do not differ significantly at $P=0.05$

Table 4. Effect of sub-lethal concentrations of emamectin benzoate, lufenuron and flufenoxuron on adult fecundity, fertility and longevity of the $2^{\text {nd }}$ instar larvae of $S$. littoralis

\begin{tabular}{|c|c|c|c|c|}
\hline Insecticide & $\begin{array}{l}\text { Conc. } \\
\left(\mathrm{mg} \mathrm{L} \mathrm{L}^{-1}\right)\end{array}$ & $\begin{array}{c}\text { Fecundity } \\
\text { (No. eggs laid / female) } \\
\pm \text { SE }\end{array}$ & $\begin{array}{c}\text { fertility } \\
\text { (percentage of } \\
\text { egg hatch) } \pm \text { SE }\end{array}$ & $\begin{array}{l}\text { Adult longevity } \\
\quad \text { (days) } \pm \text { SE }\end{array}$ \\
\hline Control & - & $544.3^{\mathrm{a}} \pm 22.5$ & $97.4^{\mathrm{a}} \pm 2.1$ & $6.5^{\mathrm{a}} \pm 0.4$ \\
\hline \multirow[t]{2}{*}{ Emamectin benzoate } & 0.001 & $507.5^{b} \pm 24.5$ & $88.5^{b} \pm 3.5$ & $6.1^{\mathrm{a}} \pm 0.3$ \\
\hline & 0.002 & $495.5^{\mathrm{b}} \pm 14.7$ & $85.8^{\mathrm{b}} \pm 4.2$ & $6.2^{\mathrm{a}} \pm 0.5$ \\
\hline \multirow[t]{2}{*}{ Lufenuron } & 0.028 & $385.3^{c} \pm 26.7$ & $76.3^{c} \pm 2.9$ & $6.7^{\mathrm{a}} \pm 0.3$ \\
\hline & 0.064 & $340.8^{\mathrm{d}} \pm 23.2$ & $64.2^{\mathrm{d}} \pm 3.5$ & $6.3^{\mathrm{a}} \pm 0.6$ \\
\hline \multirow[t]{2}{*}{ Flufenoxuron } & 0.06 & $347.6^{\mathrm{d}} \pm 12.4$ & $74.6^{\mathrm{c}} \pm 1.8$ & $6.8^{\mathrm{a}} \pm 0.5$ \\
\hline & 0.16 & $328.5^{\mathrm{d}} \pm 21.9$ & $67.7^{\mathrm{d}} \pm 2.6$ & $6.4^{\mathrm{a}} \pm 0.4$ \\
\hline
\end{tabular}

Within a column, means possessing the same letter do not differ significantly at $P=0.05$. 
Effect of emamectin benzoate, lufenuron and flufenoxuron on the PPO activity in the $S$. littoralis larvae:

Data of the in vivo effects of emamectin benzoate, lufenuron and flufenoxuron when applied to the $2^{\text {nd }}$ instar larvae of $S$. littoralis on the PPO activity after 4 days of treatment are presented in Table (5). Data showed that all treatments significantly decreased the PPO activity compared to the control. The highest inhibition was recorded with $\mathrm{LC}_{25}$ of lufenuron followed by flufenoxuron and emamectin benzoate with inhibition percentages of $60.3,58.7$ and 44.6 , respectively.

\section{DISCUSSION}

Insect management strategies must be directed towards the use of insecticides that are none or less toxic to all environmental components including the beneficial arthropods. Emamectin benzoate is less toxic to most beneficial arthropods, especially when exposure occurs beyond one day after application (Lasota and Dybas, 1991). Also, IGRs which act as chitin synthesis inhibitors or juvenile hormone analogs have been regarded as excellent integrated control insecticides because of their specificity to target pests and their general safety to vertebrates (Deakle and Bradly 1982). In field application of insecticides, some insects may expose to sub-lethal concentrations of the applied insecticide. Many sub-lethal effects on insect pests can result from that exposure.

In the present study, emamectin benzoate was approximately 34 and 83 times more toxic than lufenuron and flufenoxuron, respectively. Lufenuron was approximately 2 times more toxic than flufenoxuron against the $2^{\text {nd }}$ instar larvae of S.littoralis after $96 \mathrm{hrs}$ of exposure. Argentine et al. (2002) reported high toxicity of emamectin benzoate against six species of Lepidoptera ( $\mathrm{LC}_{90}$ ranged from 0.0050 to 0.0218 $\mu \mathrm{g} / \mathrm{ml})$. Previous studies also showed that emamectin benzoate was more toxic than lufenuron and flufenoxuron against the $2^{\text {nd }}, 3^{\text {rd }}$ and $4^{\text {th }}$ instar larvae of S. littoralis (Saad et al., 2011).

Emamectin benzoate at the two tested concentrations $\left(\mathrm{LC}_{10}\right.$ and $\left.\mathrm{LC}_{25}\right)$ significantly decreased the average weight of treated larvae, reduced pupation percentage, suppressed the pupal mean weight and reduced adult emergence rate compared to control during the observation period. Abroet al. (1993) found that abamectin significantly reduced weight gain (food consumption) by fourth instars of $P$. xylostella at $\mathrm{LC}_{5}$. In another study, when Lymantria dispar L. larvae treated with either 5.0 or $1.0 \mathrm{ppm}$ of abamectin had led to significantly reduced frass output and weight gain, indicating feeding cessation, also, delayed molting by at least $1 \mathrm{~d}$. Avermectin at all sublethal concentrations appeared to act as depressants (Deecher et al., 1990). In some dipteran larvae, sub-lethal doses of ivermectin have been reported to reduce pupation and emergence of adults (Strong, 1989). Emamectin benzoate at $\mathrm{LC}_{10}$ and $\mathrm{LC}_{25}$ when used against the $2^{\text {nd }}$ instar larvae, was also significantly decreased the average of eggs laid / female (fecundity) and percentage of egg hatch (fertility). Strong (1993) mentioned that ivermectin residues in sheep dung affected the reproduction of treated insects. So, Kruger and Scholtz (1995) reported that ivermectin diminished the fertility in adults of Musca nevilli which developed in dung from treated cattle.

Benzoylphenylureas (BPUs), are considered safe insecticides for humans and other mammals, since chitin is absent in these species (Apperson et al., 1978). In this study, lufenuron and flufenoxuron negatively affect most of the growth and development parameters when the $2^{\text {nd }}$ instar larvae of $S$. littoralis were treated by two sublethal concentrations. Lufenuron and flufenoxuron caused significant decrease of the larval body weight, increase of the average time to pupation for treated larvae, decrease of pupation percentage, suppress the mean pupal weight and reduce the adult emergence, in a concentration dependent manner, compared to control treatment.

Table 5. In vivo effect of sub-lethal concentrations of emamectin benzoate, lufenuron and flufenoxuron on the PPO activity extracted from the treated $2^{\text {nd }}$ instar larvae of $S$. littoralis after 4 days of exposure

\begin{tabular}{lccc}
\hline Insecticide & $\begin{array}{c}\text { Conc. } \\
\left(\mathbf{m g ~ L}^{-1}\right)\end{array}$ & Specific activity $\left(\mathbf{O D}_{\mathbf{4 2 0}} \mathbf{m g}\right.$ protein/hr $) \pm \mathbf{S E}$ & Inhibition \% $\pm \mathbf{S E}$ \\
\hline Control & - & $18.4^{\mathrm{a}} \pm 1.6$ & \\
Emamectin benzoate & 0.001 & $14.0^{\mathrm{b}} \pm 0.8$ & $23.78 \pm 0.76$ \\
& 0.002 & $10.2^{\mathrm{d}} \pm 0.8$ & $44.54 \pm 0.16$ \\
Lufenuron & 0.028 & $11.5^{\mathrm{cd}^{\mathrm{d}}} \pm 0.5$ & $37.34 \pm 0.91$ \\
& 0.064 & $7.3^{\mathrm{e}} \pm 0.5$ & $60.28 \pm 0.25$ \\
Flufenoxuron & 0.06 & $12.7^{\mathrm{bc}} \pm 0.7$ & $30.85 \pm 0.74$ \\
& 0.16 & $7.6^{\mathrm{e}} \pm 0.4$ & $58.61 \pm 0.48$ \\
\hline
\end{tabular}

Within a column, means possessing the same letter do not differ significantly at $P=0.05$.

1: No of eggs laid/femal

$2: \%$ of egg hatch 
Abdel Rahman et al. (2007) reported that, when the $3^{\text {rd }}$ instar larvae of $S$. littoralis were treated with lufenuron the affected larvae ceased feeding within 48 hrs. This may be the main reason for larval and pupal weight reduction. Our results are in agreement with the data of Adel (2012), who found a profoundly inhibition in the weight gain of $S$. littoralis treated larvae by lufenuron. Similar results also were recorded by Bakret al. (2010) with flufenoxuron. They mentioned that, flufenoxuron significantly increased the larval and pupal durations, on the other hand decreased the percentages of pupation and adult emergence of $S$. littoralis. Same results were recorded with chlorfluazuron and lufenuron against $S$. littoralis larvae, where all treatments succeeded to decrease the percent pupation, pupal weight and adult emergence (Sammour et al., 2008).

Chlorfluazuron and lufenuron had been reported to significantly reduce the $S$. littoralis fecundity and fertility (Sammour et al., 2008). In the present study, $S$. littoralis fecundity and fertility were significantly suppressed as a result of lufenuron and flufenoxuron treatments compared to control. Previous results confirmed what we have acquired from the results. Yamada et al. (1993) reported that, chlorfluazuron attenuated the fecundity and emergence rates on the development stage of the Plutella xylostella. Adel (2012) also reported that, lufenuron decrease the fecundity and fertility of the eggs produced by the adult progeny.

In our study, the two concentrations of emamectin benzoate, lufenuron and flufenoxuron significantly inhibit PPO of treated $S$. littoralis larvae in a concentration dependent manner. Nasr et al. (2010) recorded same results with pyriproxyfen and buprofezin against $S$. littoralis larvae. They mentioned that, the inhibition of PPO of $S$. littoralis by pyriproxyfen and buprofezin was concentration dependent. In general, further investigations were needed to clarify the interaction of IGR compounds with insect PPO activity and its impact on the insect growth. However, other studies are needed to investigate the effect of these sublethal doses on the development of resistance.

Finally, our results verified the lethal and sublethal effects of emamectin benzoate, lufenuron and flufenoxuron on the larval stage of $S$. littoralis. The sublethal concentrations of these insecticides negatively affect fertility and fecundity of $S$. littoralis. These effects are very important from a practical point of view, because offspring can then be reduced and the insect population can be negatively affected. Fortunately, the mode of action of emamectin benzoate, lufenuron and flufenoxuron is different from pyrethroid, carbamate and organophosphate insecticides. So, emamectin benzoate, lufenuron and flufenoxuron can be used for $S$. littoralis control and resistance management programs.

\section{REFERENCES}

Abbott, W.S. 1925. A method for computing the effectiveness of an insecticide. J. Econ. Entomol. 18, 265-267.

Abdel Rahman, S.M., E.M.Hegazy, A.E.Elwey.2007. Direct and latent effects of two chitin synthesis inhibitors to Spodoptera littoralis larvae (Boisd.). American-Eurasian J. Agric. Envron. Sci. 2, 457-464.

Abou-Taleb, H.K, A. S. A.Saad, H. A.Mesbah, S. M.Abdel Rahman, D. A.El-Deeb. 2009. Toxicity of emamectin benzoate against laboratory and field strains of cotton leafworm with reference to its effects on the AST, ALT and ALP activity, in Proceedings of the 6th International Symposium of Mediterranean Group on Pesticide Research (MGPR), 27-29, October, 2009, Cairo, Egypt.

Abou-Taleb, H.K. 2010. Differential toxicity of some insecticides against egg and larval stages of cotton leafworm and role of two detoxification enzymes. Alex. Sci. Exch. J. 31, 356 - 364.

Abro, G.H., T.S.Corbitt, P.T.Christie, D.J.Wright. 1993. Sublethal effects of abamectin on Plutella xylostella L. and Spodoptera littoralis Boisduval larvae. Crop Prot. 12, 3944.

Adel, M.M. 2012. Lufenuron Impair the Chitin Synthesis and Development of Spodoptera littoralisBosid (Lepidoptera: Noctuidae). J. Appl. Sci. Res. 8, 2766-2775.

Ahmad, M., M.A.Saleem. A.H.Sayyed. 2009. Efficacy of insecticide mixtures against pyrethroid- and organophosphate-resistant populations of Spodoptera littoralis (Lepidoptera: Noctuidae). Pest Manag. Sci. 65:266-274.

Andersen, S.O. 2005. Cuticular sclerotization and tanning. In: Gilbert, L.I., Iatrou, K., Gill, S.S. (Eds.), Comprehensive Molecular Insect Science,. 4. :145-170.

Apperson, C.S., C.H.Schaefer, A.E.Colwell, G.H.Werner, N.L.Anderson, E.F.Dupras, D.R.Longanecker.1978. Effects of diflubenzuron on Chaoborus astictopus and nontarget organisms and persistence of diflubenzuron in lentic habitats. J. Econ. Entomol. 71: 521-527.

Argentine, J.A., R.K.Jansson, W.R.Halliday, D.Rugg, C.S.Jany. 2002. Potency, spectrum and residual activity of four new insecticides under glass house conditions. Florida Entomologist. 85, 552-562.

Bakr, R.F.A., N.M.El-barky, M.F.AbdElaziz, M.H.Awad, M.E.Abd El-Halim. 2010. Effect of Chitin synthesis inhibitors (flufenoxuron) on some biological and biochemical aspects of the cotton leaf worm Spodoptera littoralis Bosid. (Lepidoptera: Noctuidae). Egypt. Acad. J. biolog.Sci. 2, 43- 56. 
Couty, A., a. G.de la Viñ, S.J.Clark, L.Kaiser, M.H.PhamDele` gue, G.M.Poppy. 2001. Direct and indirect sublethal effects of Galanthus nivalis agglutinin (GNA) on the development of a potato-aphid parasitoid, Aphelinus abdominalis (Hymenoptera: Aphelinidae). J. Ins. Physiol. 47, 553-561.

Cripe, G.M., C.L.Mckenney, Jr., M.D.Hoglund, P.S.Harris. 2003. Effects of fenoxycarb exposure on complete larval development of the xanthid crab, Rhithropanopeus harrisii. Environ. Pollut. 125, 295-299.

Davies, I., G.Rodger. 2000. A review of the use of ivermectin as a treatment for sea lice, Lepeophtheirus salmonis (Krøyer) and Caligus elongatus (Nordmann), infestation in farmed Atlantic salmon Salmo salar L. Aquaculture Res. 31, 869-883.

Deakle, J.P., J.R.Bradly.1982. Effects of early season applications of diflubenzuron and azinophosmethyl on population levels of certain arthropods in cotton fields. J. Ga. Entomol. Soc. 17, 200-204.

Deecher, D.C., J.Brezner, S.W.Tanenbaum.1990. Sublethal effects of avermectin and milbemycin on the gypsy moth (Lepidoptera: Lymantriidae). J. Econ. Entomol. 83, 710714.

Eldefrawi, M.E., A.Toppozada, N.Mansour, M.Zeid.1964. Toxicity studies on the Egyptian cotton leafworm, Prodenialitura. I. Susceptibility of different larval instars of Prodenia to insecticides. J. Econ. Entomo. 57, 591 593.

Finney, D.J. 1971. Probit analysis, Cambridge Univ. Press, Cambridge.

Furlong, M.J., H.J.Verkerk, D.J.Wright.1994. Differential effects of the acylurea insect growth regulator, teflubenzuron on the adult of two endolarval parasitoids of Plutella xylostella, Costesiaplutellae and Diadegma semiclousum. Pestic. Sci. 41, 359-364.

Graf, J.F. 1993. The role of insect growth regulators in arthropod control. Parasitol. 9, 471-474.

Hatem, A.E., H.B.Homam, R.A.M.Amer, S.S.M.AbdelSamad, H.A.Saleh, A.I.Hussien. 2009.Synergistic activity of several acids in binary mixtures with synthetic insecticides on Spodopter alittoralis (Boisduval).Boletin de Sanidad Vegetal Plagas. 35, 533-542.

Kruger, K., C. H.Scholtz. 1995. The effect of ivermectin on the development and reproduction of the dung-breeding fly Musc anevilli Kleynhans (Diptera: Muscidae). Agriculture, Ecosystems and Environment. 53, 13-18.

Lasota, J.A., R.A.Dybas. 1991. Avermectins, a novel class of compounds: implications for use in arthropod pest control. Annual Review of Entomology. 36, 91-117.

Liu, D.G., J.T.Trumble. 2005. Interactions of plant resistance and insecticides on the development and survival of Bactericerca cockerelli [Sulc] (Homoptera: Psyllidae). Crop Prot. 24, 111-117.

Lowery, O.H., N.J.Rosenbourgh, A.L.Farr, R.J.Rondall. 1951.Protein measurement with folin phenol reagent. J. Biol. Chem. 193, 265-275.
Mrozik, H. 1994. Advances in research and development of avermectins. Am. Chem. Soc. Symp. Ser. 551, 54-73.

Nasr, H.M., M.E.I.Badawy, E.I.Rabea. 2010. Toxicity and biochemical study of two insect growth regulators, buprofezin and pyriproxyfen, on cotton leafworm Spodopter alittoralis. Pestic.Biochem. Physiol. 98, 198205.

Oetken, M., J.Bachmann, U.Schulte-Oehlmann, J.Oehlmann.2004. Evidence for endocrine disruption in invertebrates. Int. Rev. Cytol. 236, 1-44.

Roberts, T.R., D.H.Hutson. 1999. Metabolic Pathways of Agrochemicals. The Royal Society of Chemistry, UK, p. 871.

Russell, R.M, J.L. Robertson, N.E.Savin.1977. POLO: a new computer program for Probit analysis. Bulletin of the Entomological Society of America. 23, 209-213.

Saad, A.S.A., M.A.Massoud, M.K.A.Abu-Sholoua, H.K.Abou-Taleb, E.Kotb. 2011. Toxicity of emamectin benzoate and two IGR compounds against egg masses and different larval instars of cotton leafworm. J. Adv. Agric. Rees. 16, 271-282.

Sabri, M. A., M. S. Islam, D. Hussainand M. Saleem.2017. Evaluation of lethal response of biorational insecticides against Spodoptera litura (Lipidoptera: Noctuidae ). J. Entomology. and Zoology studies 4(4): 270-274

Sammour, E.A., M.A.Kandil, N.F.Abdel-Aziz. 2008.The reproductive potential and fate of chlorfluazuron and lufenuron against cotton leafworm, Spodoptera littoralis (Bosid.).American-Eurasian J. Agric. Envron. Sci. 4, 6267.

Singh, J.P., K.K.Marwaha. 2000. Effects of sublethal concentrations of some insecticides on growth and development of maize stalk borer, Chilopartellus (Swinhoe) larvae. Shashpa. 7, 181-186.

Soderhall, K., L.Cerenius. 1998. Role of the prophenoloxidase-activating system in invertebrate immunity.Current Opinion in Immunology. 10, 23-28.

Stark, J.D., T.Rangus. 1994. Lethal and sublethal effects of the neem insecticide, Margosan-O, on the pea aphid.Pestic. Sci. 41, 155-160.

Strong, L. 1989. Sequential latent effects of a sub-lethal dose of ivermectin in Calliphora vomitoria L. Pestic. Sci. 27, 253-260

Strong, L. 1993. Overview: the impact of ivermectins on postureland ecology. Vet. Parasitol. 48, 3-17.

Tunaz, H., N.Uygun. 2004). Insect growth regulators for insect pest control. Turk. J. Agric. For. 28, 377-387.

Yamada, K., T.Tanaka, A.R.Fahmy, T.Miyata. 1993.Laboratory evaluation of the biological fitness of chlorfluazuron resistant and susceptible strains from the same origin of the diamondback moth, Plutella xylostella. Appl. Entomol. Zool. 28, 396-399. 
Yin, X.H., Wu, Q.J., Li, X.F., Y.J.Zhang, B.Y.Xu. 2008. Effect of sublethal concentrations of spinosad on the activities of detoxifying enzymes in the larvae of diamondback moth Plutella xylostella. Chin. J. Pestic. Sci. 10, 28-34 (in Chinese).
Zalizniak, L., D.Nugegoda. 2006. Effect of sublethal concentrations of chlorpyrifos on three successive generations of Daphnia carinata.Ecotoxicol. Environ. Saf. 64, 207-214.

Zhi-qing, M.A., H.Xiu-ling, F.Jun-tao, L.Guang-ze, Z.Xing. 2008.Effects of Terpinen-4-ol on four metabolic enzymes and polyphenol oxidase (PPO) in Mythimna separta Walker, Agric. Sci. China. 7, 726-730.

\section{الملخص العربي}

التأثير ات البيوكيميائية والبيولوجية للجرعات التحت مميتة لمبيدات الإيماميكتين بنزوات وبعض منظمات

\section{النمو الحشرية ضد دودة ورق القطن}

ايمان قطب السيد، مجدى عبد الظاهر، منال أحمد عطية

انخفضت فترة تحول اليرقات لعذارى عند نركيزات LC

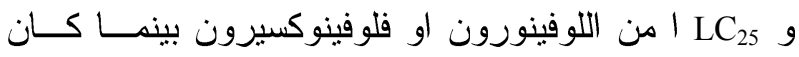

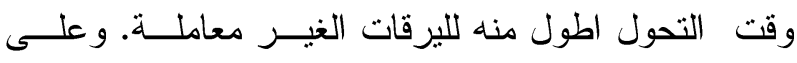

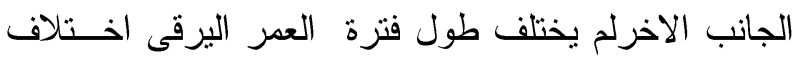
معنوى فى كل من اليرقات المعاملـــة بكــلا التركيـزين

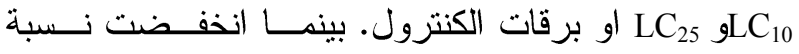

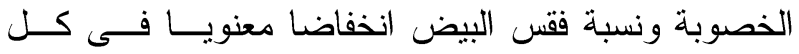
المعاملات مقارنة بالكنترول.كذالك اظهرت النتائج اتخفاض نشاط اتزيم البولى فينول أوكسيديز فى كل المعاملات وهذا

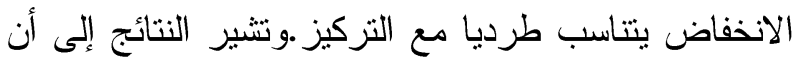

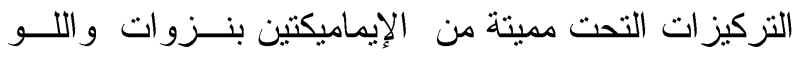
فينوزون وفلوفينوكسيرون قد تؤدى الى انخفاض معـدلات الزيادة فى تعداد يرقات دودة ورق القطن وذلك عن طريق التأثير على تطور ها وتكاثز ها.
تم تقييم السمية وتأثثرات الجرعــات التحـــت المميتــة

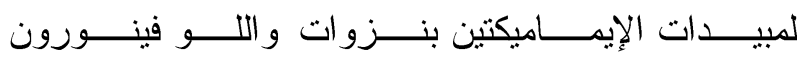

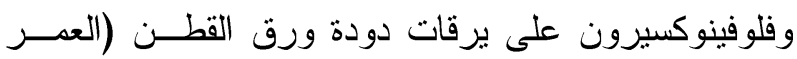

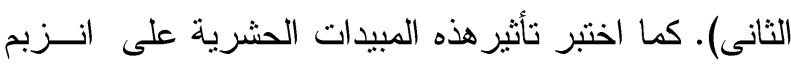

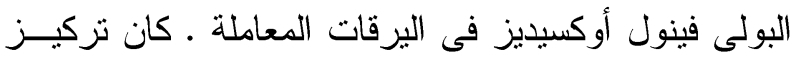

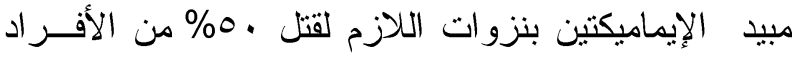

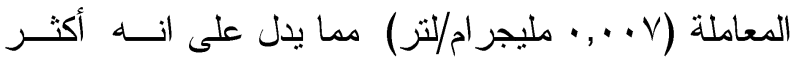

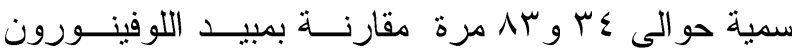

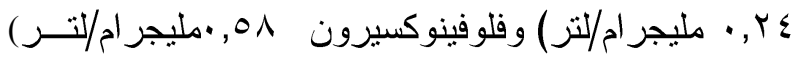
على التو الى. بينما كانت سمية اللوفينورون ضعف سئسية الفلوفينو كسبرون. وقد أظهرت النتائج انخفاض معنوى فى وزن اليرقات ونسبة تحول اليرقات لعذارى ومتوسط وزن العذارى ومعدل خروج الحشر ات الكاملة عند معاملة يرقات

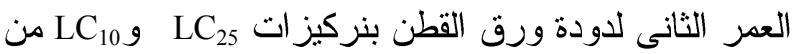

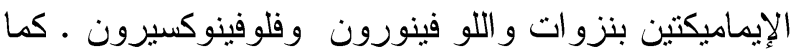

